\title{
THE MOONSCAPE OF TAX EQUALITY: WINDSOR AND BEYOND
}

\author{
Anthony C. Infanti ${ }^{*}$
}

\section{INTRODUCTION}

From a distance, the moon appears bright, shiny, and attractive. It is revered and romanticized. Lives (and deaths) are planned around its phases and cycles. But, upon closer inspection, this attractive object is actually scarred-pocked with craters left by past violent impacts. For same-sex couples, federal tax equality shares a strikingly similar duality.

In its eagerly anticipated decision in United States v. Windsor, the U.S. Supreme Court invalidated Section 3 of the federal Defense of Marriage Act (DOMA) in a suit where a surviving same-sex spouse sought a refund of federal estate taxes. ${ }^{1}$ Before its demise, DOMA purported to defend against the onslaught of same-sex couples seeking to destroy "traditional" marriage. ${ }^{2}$ Departing from the federal government's long tradition of deferring to state law on questions of marital status, DOMA denied federal recognition to same-sex marriages recognized under state law. ${ }^{3}$ In Windsor, DOMA operated to "protect" traditional marriage by forcing an estate to pay $\$ 363,053$ of federal estate tax on a transfer of property to the (female) decedent's (female) spouse, when the decedent's estate would have owed nothing had the transfer been to the (female) decedent's (male) spouse. ${ }^{4}$ With DOMA now relegated to the constitutional dustbin, it would seem that all married couples - regardless of gender and sexual orientation - are on an equal legal plane (at least from the perspective of federal law).

\footnotetext{
* Associate Dean for Academic Affairs and Professor of Law, University of Pittsburgh School of Law. Thanks to the participants at the workshop "After Equality: Family, Sex, Kinship" at McGill University Faculty of Law - particularly, the workshop organizer, Robert Leckey — for comments on an early draft of this Essay. And thanks to the staff of the Northwestern University Law Review Colloquy for their helpful assistance and suggestions during the editing process.

${ }^{1}$ Defense of Marriage Act, Pub. L. No. 104-199, § 3, 110 Stat. 2419 (1996) (codified at 1 U.S.C. $\S 7$ (2012)), invalidated by United States v. Windsor, 133 S. Ct. 2675 (2013).

2 See H.R. REP. No. 104-664, at 2-3 (1996), reprinted in 1996 U.S.C.C.A.N. 2905, 2906-07 (describing "the orchestrated legal assault being waged against traditional heterosexual marriage by gay rights groups and their lawyers").

3 See Boyter v. Comm'r, 668 F.2d 1382, 1385 (4th Cir. 1981) ("We agree with the government's argument that under the Internal Revenue Code a federal court is bound by state law rather than federal law when attempting to construe marital status."); H.R. REP. NO. 104-664, at 2-3, reprinted in 1996 U.S.C.C.A.N. at 2906-07.

4 Windsor, 133 S. Ct. at 2683.
} 
In the abstract, invalidating DOMA and its unequal treatment of married couples based on their gender and sexual orientation is appealing. Like the moon, it draws us in with its own romanticized sort of beauty. But when we come face to face with legal equality, we may find that it is not so bright, shiny, and attractive. What we will learn is that federal tax equality is pocked and scarred by the impact of past legal battles that make it less promising and attractive. Indeed, we will find that "equality" is decidedly not equal, and that the federal tax situation post-Windsor may be markedly worse than pre-Windsor.

In Part I of this Essay, I describe the path that led to the decision in Windsor. Then, in Part II, I turn to describing the ways in which the postWindsor tax terrain may actually be worse for same-sex couples than the bleak tax landscape they faced before that decision. This is important because, while other federal laws will apply to some couples some of the time, the federal tax laws are a concern for all of us on an annual (or even more frequent) basis. Under DOMA, same-sex couples already faced a debilitating level of uncertainty in determining how the federal tax laws applied to their relationships. Post-Windsor, same-sex couples will see this uncertainty multiply - even after receiving guidance from the Internal Revenue Service (IRS) on the implementation of the Windsor decision in the federal tax context. They will have to grapple not only with lingering questions surrounding the federal tax treatment of relationships that are not recognized, but also with new questions regarding whether and how their relationships will be recognized for federal tax purposes. Moreover, it seems that dispatching discrimination designed to erode the progress of same-sex couples toward formal equality has served only to entrench the privileged status of marriage in our federal tax laws rather than to foster the recognition of a broader array of human relationships. This Essay ends with brief concluding remarks.

\section{EQUALITY ARRIVED}

From 1996 until 2013, Section 3 of DOMA provided that, for purposes of federal law, "the word 'marriage' means only a legal union between one man and one woman as husband and wife, and the word 'spouse' refers only to a person of the opposite sex who is a husband or a wife." 5 The effect of this provision was to deny same-sex couples the important tax benefits (and to spare them the tax detriments) that accompany marriage. Following its enactment, DOMA was the subject of legal challenges, the earliest of which found that the statute passed constitutional muster. ${ }^{6}$ The constitutional tide began to turn, however, in the late 2000s. Unsurprisingly,

\footnotetext{
5 Defense of Marriage Act $§ 3(a)$.

${ }^{6}$ See Wilson v. Ake, 354 F. Supp. 2d 1298 (M.D. Fla. 2005); In re Kandu, 315 B.R. 123 (Bankr. W.D. Wash. 2004).
} 
a number of these decisions centered specifically on DOMA's application to the federal tax laws.

Starting in 2010, the federal court decisions invalidating Section 3 of DOMA began to accumulate. First, in Gill v. Office of Personnel Management, ${ }^{7}$ a U.S. district court found "that 'there exists no fairly conceivable set of facts that could ground a rational relationship' between DOMA and a legitimate government objective." ${ }^{\prime 8}$ Gill involved an equal protection challenge to DOMA's denial of a number of federal benefits (including federal income tax benefits) to a group of same-sex couples. In that case, the court found that DOMA "violate[d] core constitutional principles of equal protection" and that all of the proffered rationales for enacting DOMA were implausible. ${ }^{10}$ According to the court, the only plausible explanation was that DOMA was borne of "irrational prejudice" and "animus" toward same-sex couples. ${ }^{11}$

In 2012, three additional district courts invalidated DOMA, and a federal appellate court did so for the first time. In Dragovich v. U.S. Department of the Treasury, ${ }^{12}$ a group of California public employees challenged the constitutionality of Section 3 of DOMA and its interaction with I.R.C. $\S 7702 \mathrm{~B}(\mathrm{f})$. These laws prevented the employees' same-sex spouses and registered domestic partners from enrolling in the state's longterm care plan, which is afforded favorable federal tax treatment. The U.S. district court found that neither DOMA nor $\S 7702 \mathrm{~B}$ (f) bore any rational relationship to a legitimate government interest. To the contrary, the court found that both statutes were motivated by actual or apparent antigay animus. ${ }^{13}$ Accordingly, the court held that both statutes violated the plaintiffs' equal protection rights. ${ }^{14}$ In Pedersen v. Office of Personnel Management,${ }^{15}$ another U.S. district court considered a challenge similar to that in Gill. Although the Pedersen court determined that sexual orientation classifications should be subject to heightened scrutiny, it concluded that Section 3 of DOMA could not survive even rational basis review. ${ }^{16}$ In Windsor v. United States,${ }^{17}$ another U.S. district court found that Section 3 of DOMA violated the equal protection rights of a surviving same-sex

\footnotetext{
7699 F. Supp. 2d 374 (D. Mass. 2010), aff'd sub nom. Massachusetts v. U.S. Dep't of Health \& Human Servs., 682 F.3d 1 (1st Cir. 2012), cert. denied, 133 S. Ct. 2887 (2013).

${ }^{8}$ Id. at 387 (footnote omitted) (quoting Medeiros v. Vincent, 431 F.3d 25, 29 (1st Cir. 2005)).

9 Id.

10 See id. at 396.

11 Id. at 396-97.

12872 F. Supp. 2 d 944 (N.D. Cal. 2012).

13 Id. at 955.

14 Id. at $959,964$.

15881 F. Supp. 2d 294 (D. Conn. 2012).

16 Id. at 334.

17833 F. Supp. 2d 394 (S.D.N.Y.), aff'd 699 F.3d 169 (2d Cir. 2012), aff'd sub nom. United States v. Windsor 133 S. Ct. 2675 (2013).
} 
spouse when the surviving spouse had been required to bear the burden of federal estate taxes because she was unable to qualify for the estate tax marital deduction. ${ }^{18}$

In May 2012, the U.S. Court of Appeals for the First Circuit affirmed the Gill decision, issuing the first ruling from a federal appellate court finding Section 3 of DOMA unconstitutional. In its decision, the First Circuit was diffident, asserting that DOMA would actually survive the traditional rational basis test because "Congress could rationally have believed that DOMA would reduce costs, even if newer studies of the actual economic effects of DOMA suggest that it may in fact raise costs for the federal government." 19 Ultimately, however, the First Circuit decided that "the extreme deference accorded to ordinary economic legislation" was inappropriate in light of the federalism concerns raised by DOMA's intrusion "on matters customarily within state control." 20 Accordingly, the court instead applied a more searching form of rational basis scrutiny, as had been done in other cases where a classification targets a "historically disadvantaged or unpopular" group. ${ }^{21}$ Disavowing any reliance upon antigay animus as a basis for its decision, the First Circuit held that DOMA could not pass muster under this more searching form of rational basis scrutiny, stating that "[s]everal of the reasons given [in support of DOMA] do not match the statute and several others are diminished by specific holdings in Supreme Court decisions more or less directly on point."2

Just seven months later, the U.S. Supreme Court decided to hear an appeal in Windsor. ${ }^{23}$ On June 26, 2013, a sharply divided Supreme Court issued a decision in that case invalidating Section 3 of DOMA. ${ }^{24}$ In the majority opinion, the Windsor Court elided the question of the appropriate standard of review under equal protection analysis; however, it did seem to apply something more than traditional rational basis review to the taxpayer's claim. ${ }^{25}$ In reaching its decision, the majority drew upon federalism concerns-given that questions of marital status have historically been left to the states - but relied more directly upon the antigay animus underlying DOMA's enactment. ${ }^{26}$ Ultimately, the Court held that

\footnotetext{
18 Id. at 396; see also I.R.C. § 2056 (2006).

19 Massachusetts v. U.S. Dep't of Health \& Human Servs., 682 F.3d 1, 9 (1st Cir. 2012), cert. denied, 133 S. Ct. 2887 (2013).

${ }^{20} I d$. at $11,13$.

21 Id. at $10-11$.

22 Id. at 15.

23 Windsor v. United States, 699 F.3d 169, cert granted, 133 S. Ct. 768 (2012), aff'd, 133 S. Ct. 2675 (2013).

24 Windsor, 133 S. Ct. 2675.

25 See id. at 2693 (subjecting DOMA to "careful consideration"); see also id. at 2706 (Scalia, J., dissenting) (observing that the majority "does not apply anything that resembles th[e] deferential framework" of rational basis analysis).

26 Id. at 2689-96 (majority opinion).
} 
Section 3 of DOMA "is invalid, for no legitimate purpose overcomes the purpose and effect to disparage and to injure those whom the State, by its marriage laws, sought to protect in personhood and dignity."27

\section{Not So EQUAL AfTER ALL}

In the absence of Section 3 of DOMA, the question of whether samesex couples are considered married for federal tax purposes is determined by reference to state law. Thus, same-sex couples are now ostensibly on the same legal footing as different-sex couples for purposes of federal tax law. In reality, however, invalidating Section 3 of DOMA does not, by itself, bring about tax equality in any meaningful sense. Nor does it merely return same-sex couples to the status quo of blanket discrimination that preceded the enactment of DOMA. Instead, because of the pocks and scars left by legal battles that took place in the shadow of DOMA, invalidating Section 3 of DOMA will likely worsen the legal position of same-sex couples and further entrench the privileging of marriage in the federal tax laws.

\section{A. A Shifted and Shifting Legal Landscape}

Fearing that the Hawaii courts were poised to legally recognize samesex marriages, Congress was motivated to codify what was then the norm of denying legal recognition to same-sex relationships. ${ }^{28}$ In other words, Congress's enactment of Section 3 of DOMA merely substituted a single federal rule denying legal recognition to same-sex relationships for fifty state rules that had previously had the same effect. Accordingly, from the perspective of same-sex couples, Section 3 of DOMA had no immediate impact on how they were treated under federal law - they were treated the same the day after Congress enacted DOMA as they had been the day before.

The legal landscape at the state level did change for same-sex couples, but not as quickly or in the way that Congress had envisioned. It was not until 1999, when Vermont created the first "civil union" regime in the United States, ${ }^{29}$ that the first state extended all of the rights and obligations of marriage to same-sex couples. And it was not until 2003 that Massachusetts became the first state to extend the right to marry to samesex couples. ${ }^{30}$ Since then, same-sex couples have experienced significant advances in obtaining legal recognition for their relationships.

At the time of this Essay's publication, the District of Columbia and thirteen states (i.e., California, Connecticut, Delaware, Iowa, Maine,

\footnotetext{
27 Id. at 2696.

28 H.R. REP. No. 104-664, at 10 (1996), reprinted in 1996 U.S.C.C.A.N. 2905, 2914.

29 Act Relating to Civil Unions, § 3, 2000 Vt. Adv. Legis. Serv. 91 (LexisNexis).

30 Opinions of the Justices to the Senate, 802 N.E.2d 565 (Mass. 2004); Goodridge v. Dep’t of Pub. Health, 798 N.E.2d 941 (Mass. 2003).
} 
Maryland, Massachusetts, Minnesota, New Hampshire, New York, Rhode Island, Vermont, and Washington) permit same-sex couples to marry. ${ }^{31}$ Five other states (i.e., Hawaii, Illinois, Nevada, New Jersey, and Oregon) do not permit same-sex marriages, but do permit same-sex couples to enter into legally equivalent relationships. ${ }^{32}$ Two states (i.e., Colorado and Wisconsin) only permit same-sex couples to enter into legal relationships that afford something less than all of the rights and obligations of marriage. ${ }^{33}$ In contrast, thirty-five states have a constitutional or statutory prohibition against same-sex marriage. ${ }^{34}$ Interestingly, among the states that prohibit same-sex marriage, only twenty-nine afford no legal recognition to samesex relationships. ${ }^{35}$ The other six states actually do legally recognize samesex relationships - four of them have civil union or domestic partnership regimes that withhold nothing from same-sex couples other than the marriage label, and the other two permit same-sex couples to enter into relationships with lesser rights and obligations.

Now forced to abandon its uniform federal definition of (non)marriage for same-sex couples, the federal government will not simply return to relying upon a uniform set of state rules that will have the same effect. Instead, invalidating Section 3 of DOMA will cause the federal government to embrace a significantly changed legal landscape for purposes of determining who is (or is not) married for federal tax purposes. This legal landscape is not only far different from the one that existed in 1996 but also a complex and ever-shifting one.

The shifting landscape is largely a product of federalism and its supposed incarnation in Section 2 of DOMA. Section 2 of DOMA purports to authorize states to refuse legal recognition to same-sex marriages validly contracted in other states. ${ }^{36}$ The ostensible purpose of this provision is to permit each state to make the decision whether to legally recognize samesex relationships, without having to give effect to another state's choice regarding this question. ${ }^{37}$ The practical impact of this provision is to cause

31 Human Rights CAMPAign, Marriage EQuality AND Other RElationship ReCOGNITION LAWS (2013), available at http://www.hrc.org/files/assets/resources/marriage_equality_082013.pdf.

$32 \mathrm{Id}$.

33 Id. Colorado has enacted a civil union regime that purports to afford same-sex couples all of the rights and obligations of marriage. S. 13-011, 69th Gen. Assemb., 1st Reg. Sess. (Colo. 2013) (enacting COLO. REv. STAT. § 14-15-107). However, this law specifically withheld from same-sex couples the right to file joint state income tax returns on the ground that Colorado's income tax incorporates the federal income tax by reference, at the time of the regime's enactment, and same-sex couples were not permitted to file joint federal income tax returns. Id. § 14-15-117.

34 Human Rights CAMPAign, Statewide Marriage Prohibitions (2013), available at http://www.hrc.org/files/assets/resources/marriage_prohibitions_072013.pdf.

35 Compare id., with Human Rights CAMPAign, MARRIAGE EQUALity AND OTHER RElationshiP RECOGNITION LAWS, supra note 31.

36 See 28 U.S.C. $\$ 1738 \mathrm{C}(2006)$.

37 See H.R. REP. No. 104-664, at 6-10 (1996), reprinted in 1996 U.S.C.C.A.N. 2905, 2910-14. 
the legal recognition of same-sex relationships to appear and disappear as couples cross state borders. For example, a same-sex couple married in Massachusetts will see the legal recognition of their relationship disappear when they visit Pennsylvania or enter into a transaction in Ohio because those states refuse to legally recognize same-sex relationships. ${ }^{38}$ Even among the states that legally recognize same-sex relationships, it is not clear that the Massachusetts couple's marriage would be honored. For instance, Nevada and Oregon may recognize the couple's relationship as a domestic partnership (but not as a marriage); however, it appears that the couple would have to separately register as domestic partners in those states before their relationship would be recognized. ${ }^{39}$ In contrast, a different-sex couple married in Massachusetts would not encounter any uncertainty regarding the recognition of their relationship because their relationship would be recognized in every state as a routine matter. ${ }^{40}$

\section{B. Uncertainty, Uncertainty, and More Uncertainty}

1. Uncertainty Pre-Windsor.-Even under DOMA's ostensibly simple rule of legal nonrecognition, same-sex couples faced debilitating uncertainty regarding the application of the federal tax laws to their relationships. Decreeing that same-sex couples were not married for federal tax purposes answered many simple questions - for example, same-sex couples could not file joint federal income tax returns ${ }^{41}$ or benefit from the rules that shield property transfers between spouses from tax. ${ }^{42}$ But DOMA did nothing to tell same-sex couples how the tax laws applied to their relationships in more ambiguous circumstances. For instance, same-sex couples with unequal earnings who commingled their finances were given no guidance on how to treat the transfer that effectively took place each year from the higher-earning spouse to the lower-earning spouse. Yet this is just the type of entanglement and commitment that would be expected of couples and that has been relied upon to make marital status a factor in

38 OHIO CONST. art. XV, § 11; 23 PA. CONS. STAT. ANN. § 1704 (2010).

39 NEV. ReV. StAT. ANN. § 122A.500 (LexisNexis 2010); OR. CONST. art. XV, § 5a (prohibiting the legal recognition of same-sex marriages); OR. REV. STAT. §§ 106.300-.340 (2011) (establishing a domestic partnership regime but containing no provision regarding the recognition of out-of-state legal relationships as domestic partnerships); BASIC RIGHTS OR., DOMESTIC PARTNERSHIP RESOURCE GUIDE 4 (2007) (advising same-sex couples to register as domestic partners in Oregon, even if they have obtained a domestic partnership or civil union in another state), available at http://www.basicrights.org/wp-content/uploads/2011/09/BRO-Domestic-Partnership-Resource-Guide2008.pdf.

40 See RESTATEMENT (SECOND) OF CONFLICT OF LAWS $§ \S 283-84$ (1971).

41 I.R.C. $\$ 6013(\mathrm{a})(2006)$.

42 Id. $\S \S 1041,2056,2523$. 
determining tax consequences. ${ }^{43}$ The courts and the IRS did little to fill this gap. ${ }^{44}$ Indeed, in 2010, the National Taxpayer Advocate "sharply criticized the IRS for failing to provide generally applicable, precedential guidance to same-sex couples concerning the application of the federal tax laws to them." ${ }^{45}$

Returning to a derivative definition of marriage for federal tax purposes promises only to multiply the debilitating tax uncertainty that accompanied DOMA. Now, in addition to figuring out how to apply the tax laws to their relationships when they are not recognized, same-sex couples will have to figure out when their relationships will be recognized for federal tax purposes. The question of who is married-and when - arises because of the interaction of (1) the patchwork of state recognition of samesex relationships with (2) the less-than-clear rules for determining a couple's marital status. ${ }^{46}$ Justice Scalia was, therefore, absolutely correct when he pointed out in his dissent in Windsor that striking down DOMA raises "difficult choice-of-law issues." 47

2. Uncertainty Post-Windsor.-In the wake of Windsor, President Obama "directed his administration to find ways to make sure gay couples

${ }^{43}$ For a fuller explanation of the uncertainties faced by same-sex couples under DOMA, see Anthony C. Infanti, Deconstructing the Duty to the Tax System: Unfettering Zealous Advocacy on Behalf of Lesbian and Gay Taxpayers, 61 TAX LAW. 407, 423-36 (2008).

44 Anthony C. Infanti, LGBT Taxpayers: A Collision of "Others," 13 GEO. J. GENDER \& L. 1, 18-20 (2012).

45 Id. at 19; see also 1 TAXPAYER ADVOCATE SERV., I.R.S., NAT'L TAXPAYER ADVOCATE: 2012 ANNUAL REPORT TO CONGRESS 450 (2012) (indicating that, since the issuance of its 2010 report containing this criticism, "the IRS has published guidance for relatively discrete populations" of samesex couples).

46 In the absence of controlling rules in the Internal Revenue Code or Treasury Regulations, the courts and the IRS have articulated a number of different standards for determining choice of law questions regarding marital status. Many courts have stated that the law of the couple's domicile controls. See, e.g., Boyer v. Comm'r, 732 F.2d 191, 194 (D.C. Cir. 1984). Other courts have referred to the legally distinct concept of the taxpayer's residence in determining which state's law controls. See, e.g., Peveler v. Comm'r, 48 T.C.M. (P-H) II 79,460 (1979). Yet other authorities have disregarded the current state of residence or domicile and have looked to the law of the state where the marriage was entered into. See, e.g., Chagra v. Comm'r, 68 T.C.M. (RIA) II 91,366, at 91-1839 n.3 (1991); Rev. Rul. 58-66, 1958-1 C.B. 60. In the context of determining whether a marriage has ended (and a new one has begun) and whether a couple could file a joint return, the IRS has respected one state's waiving of another state's waiting period for remarriage following a divorce. Rev. Rul. 29, 1953-1 C.B. 67. In addition, some courts have honored a divorce granted by a state other than the state of marital domicile, notwithstanding that a court in the state of marital domicile had ruled that the divorce was invalid. E.g., Feinberg v. Comm'r, 198 F.2d 260, 263 (3d Cir. 1952). For married different-sex couples, many of the difficult issues that same-sex couples will now face have likely been elided because of the easy portability of a different-sex couple's marital status throughout the United States. See supra note 40 and accompanying text. For a discussion of the IRS's position on this question with respect to same-sex marriages, see infra note 49 and accompanying text.

47 United States v. Windsor, 133 S. Ct. 2675, 2708 (2013) (Scalia, J., dissenting). 
receive[] the benefits for which they [a]re now eligible." 48 Just two months later, the IRS issued its first guidance implementing the Windsor decision. Under that guidance, the IRS will recognize "a marriage of same-sex individuals that was validly entered into in a state whose laws authorize the marriage of two individuals of the same sex even if the married couple is domiciled in a state that does not recognize the validity of same-sex marriages." 49 The IRS chose this rule to avoid the difficult questions that would arise if marital status were determined based on the taxpayer's domicile, with marriages possibly appearing and disappearing each time a taxpayer moves. ${ }^{50}$ According to the Secretary of the Treasury, this "ruling provides certainty and clear, coherent tax-filing guidance for all legally married same-sex couples nationwide." ${ }^{51}$ Upon closer inspection, however, this ruling provides no more than the same veneer of clarity that DOMA did, as it leaves important questions unanswered, lays traps for the unwary, creates inequities, and entails unfortunate (and, hopefully, unintended) consequences.

a. Evasive marriages.-At different points in its guidance, the IRS speaks of recognizing the marriages of same-sex couples who are "lawfully married" or a marriage that was "valid in the state where it was entered into." 52 This raises a question regarding what the IRS means when it refers to "valid" or "lawful" marriages. Will the IRS require only that the couple have observed the legal formalities imposed by the state of celebration? Or does the IRS have a broader notion of validity in mind?

In its guidance, the IRS seems to address only the situation faced by couples in so-called migratory marriages. In other words, the IRS seems to focus on couples who are domiciled in a state that recognizes same-sex marriage, who marry in that state, and who later move to a state that refuses to recognize their marriage:

Under this rule, individuals of the same sex will be considered to be lawfully married under the Code as long as they were married in a state whose laws authorize the marriage of two individuals of the same sex, even if they are domiciled in a state that does not recognize the validity of same-sex marriages. For over half a century, for Federal income tax purposes, the Service has recognized marriages based on the laws of the state in which they were entered into, without regard to subsequent changes in domicile, to achieve uniformity, stability, and efficiency in the application and administration of the Code. Given our increasingly mobile society, it is

\footnotetext{
48 Michael D. Shear, Obama, in Africa, Praises U.S. Ruling on Gay Marriage, N.Y. TIMES (June 27, 2013), http://www.nytimes.com/2013/06/28/world/africa/obama-in-africa.html.

49 Rev. Rul. 2013-17, 2013-38 I.R.B. 201.

50 See id.

51 Annie Lowrey, IRS to Recognize Gay Couples, Regardless of State Measures, PITTSBURGH PostGaZETTE, Aug. 30, 2013, at A-6.

52 Rev. Rul. 2013-17, 2013-38 I.R.B. 201.
} 
important to have a uniform rule of recognition that can be applied with certainty by the Service and taxpayers alike for all Federal tax purposes. Those overriding tax administration policy goals generally apply with equal force in the context of same-sex marriages. ${ }^{53}$

This passage makes it clear that the status of migratory couples will not change merely by reason of a change of domicile. The paragraphs that immediately follow this passage reinforce the impression that the IRS only had migratory marriages in mind when it drafted the revenue ruling, as these paragraphs focus exclusively on the advantages of a uniform approach when couples change their domicile by moving from state to state. ${ }^{54}$

But what about couples who enter into so-called evasive marriages? An evasive marriage occurs when a couple domiciled in a state that does not recognize same-sex marriage travels to another state to marry and immediately returns to their state of domicile to live. For instance, a Pennsylvania same-sex couple might travel to New York to marry and then return to Pennsylvania to live as a couple. Regarding the validity of this marriage, the Restatement (Second) of Conflict of Laws provides that "[a] marriage which satisfies the requirements of the state where the marriage was contracted will everywhere be recognized as valid unless it violates the strong public policy of another state which had the most significant relationship to the spouses and the marriage at the time of the marriage." 55 A court applying the Restatement (as Pennsylvania has done in the past) could invalidate this evasive marriage because the couple's state of domicile (i.e., Pennsylvania) has a strong public policy against same-sex marriage. ${ }^{56}$

Are the many same-sex couples in evasive marriages now considered "married" for federal tax purposes? ${ }^{57}$ The IRS guidance does not even

53 Id. (emphasis added).

54 Id.

55 Restatement (SECOND) OF CONFLICT OF LAWS § 283(2) (1971) (emphasis added).

5623 PA. CONS. STAT. § 1704 (2013) ("It is hereby declared to be the strong and longstanding public policy of this Commonwealth that marriage shall be between one man and one woman. A marriage between persons of the same sex which was entered into in another state or foreign jurisdiction, even if valid where entered into, shall be void in this Commonwealth.”); RESTATEMENT (SECOND) OF CONFLICT OF LAWS $§ 283(2) \mathrm{cmt}$. k ("To date . . a marriage has only been invalidated when it violated a strong policy of a state where at least one of the spouses was domiciled at the time of the marriage and where both made their home immediately thereafter."); see In re Estate of Lenherr, 314 A.2d 255, 258-59 (Pa. 1974) (applying the Restatement in determining whether an evasive marriage to a paramour should be recognized for inheritance-tax purposes).

57 And if these marriages are invalid, could the IRS treat these same-sex couples as married for federal tax purposes even if it wished to? Where does the IRS derive the authority to recognize marriages that are invalid; that is, that are not really marriages at all under state law? This would certainly go well beyond the IRS's authority to interpret the Internal Revenue Code because it would put the IRS in the position of establishing its own rules for marriage. See I.R.C. § 7805(a) (2006). Furthermore, it seems logically inconsistent for the IRS, on the one hand, to legally recognize the relationships of couples who have made a legally ineffectual commitment to each other (but who have 
acknowledge - much less address - this category of marriages. Is it enough that these couples satisfied the legal formalities imposed by the state where they were married? Or, as the IRS guidance seems to say, are they now compelled to obtain expensive legal opinions regarding the validity of their marriages prior to filing their tax returns or even reporting to their employers that they are married (so that their fringe benefits are appropriately treated for tax purposes)? What if a same-sex couple cannot afford a legal opinion? Do they risk penalties if the position they take on their tax return proves to be incorrect? ? $^{58}$

Even if evasive marriages are recognized, that will have the effect of drawing a line between the haves and have-nots. In other words, it would create a legal distinction between two classes of same-sex couples residing in the same state: those who can afford to travel to, and marry in, another state that recognizes same-sex marriage and those who cannot afford to do so. In an unfortunate intersection of class with marital status, the federal tax treatment of same-sex couples would then turn on whether a couple is wealthy enough to travel across state lines to marry.

b. Continued relevance of state law.-Notwithstanding the claim that the IRS guidance is "clear" and "coherent" and provides "certainty," 59 there are many tax questions that it does not raise or answer. The IRS guidance only provides the rule for determining marital status where the Internal Revenue Code directly makes marriage relevant to the determination of tax consequences. As stated in the guidance, "[f]or Federal tax purposes, the terms 'spouse,' 'husband and wife,' 'husband,' and 'wife' include an individual married to a person of the same sex if the individuals are lawfully married under state law, and the term 'marriage' includes such a marriage between individuals of the same sex." 60 There are, however, many instances in which marital status is relevant to the determination of federal tax consequences only indirectly through the application of state law. The IRS guidance does not address these situations, and, in the absence of a federal rule, state law will control. But which state's law?

For example, the existence of a parent-child relationship can be relevant to determining the federal tax treatment of both the parent and the child. The existence of parent-child relationships, which often turn on the

nonetheless managed to obtain a piece of paper from a state with the word marriage on it) and, on the other hand, to refuse to legally recognize the relationships of the many couples who have made the same commitment in a fashion that actually affords them all of the legal rights and obligations of marriage (but who have only managed to obtain a piece of paper from the state with the words civil union or domestic partnership on it). See infra Part II.B.2.d.

58 See I.R.C. §6662(b)(1), (c) (applying a penalty for "[n]egligence or disregard of rules or regulations"). Taxpayers may avoid the penalty if they can demonstrate reasonable cause for their underpayment of tax and that they acted in good faith. Id. $\$ 6664(\mathrm{c})$.

59 Lowrey, supra note 51.

${ }^{60}$ Rev. Rul. 2013-17, 2013-38 I.R.B. 201. 
marital status of the parents, will continue to be determined under state law. Under the IRS guidance, a same-sex couple living in a state that recognizes same-sex marriage, who marry there, and who later move to a state that refuses to recognize their marriage will continue to be treated as married for federal tax purposes. If this couple has one or more children after the move, which state's law will determine parentage? The choice of law can be important because the state of the marriage's celebration might have treated both spouses as parents of the child automatically, ${ }^{61}$ but the new state-one that refuses to recognize the couple's relationship - might provide no means for establishing a legal relationship between the child and the nonbiological parent. $^{62}$

Will such a child be a "qualifying child" of the nonbiological parent for federal tax purposes? Will the child be considered related to the nonbiological parent for purposes of rules attributing ownership from parents to children (or vice versa) ${ }^{63}$ What if the nonbiological parent passes away and neither the spouse nor the child are to receive any of the decedent's property under a will or intestate succession, but a relative who is to receive the property wishes to disclaim in favor of the surviving spouse or child and to transfer the property directly to them? Will that be an effective disclaimer for federal estate and gift tax purposes if the property would have passed to the surviving spouse or child under the laws of the state of the marriage's celebration but not under the law of the state of the decedent's domicile? ${ }^{64}$

The IRS guidance does not address how far it will apply the law of the state of a marriage's celebration for federal tax purposes. It is thus unclear whether the federal tax laws will afford same-sex couples all of the rights and obligations that would have attended their marriages had they remained domiciliaries of the state of celebration. This is just the type of uncertainty that the IRS guidance purports to eliminate when it eschews determining marital status based on domicile and instead applies the law of the place of celebration. The burden of grappling with the uncertainties raised by this lacuna will fall on same-sex couples, who will now require the aid of expensive tax lawyers and accountants to resolve these questions (if they

61 See, e.g., MASS. ANN. LAWs ch. 46, § 4B (LexisNexis 2006) ("Any child born to a married woman as a result of artificial insemination with the consent of her husband, shall be considered the legitimate child of the mother and such husband."); see also Della Corte v. Ramirez, 961 N.E.2d 601, 602-03 (Mass. App. Ct. 2012) (finding that a lesbian couple who conceived through artificial insemination, married in the state, and then gave birth to a child in the same state, resulted in the child being a legitimate child of both parties).

62 Human Rights CAmpaign, PAREnting Laws: SECOND PARENT OR STEPPARENT Adoption (2013), available at http://www.hrc.org/files/assets/resources/parenting_second-parent-adoption_ 082013.pdf.

63 See I.R.C. §§ 152(a)(1), 267(b)(1), 267(c)(4), 318(a)(1); id. § 152(c) (Supp. 2012).

64 Id. § 2518(c)(3); H.R. REP. No. 97-201, at 190-91, reprinted in 1981-2 C.B. 352, 392 (“Local law will be applicable to determine the identity of the transferee."). 
can be resolved at all). Again implicating the intersection of class with marital status, wealthier same-sex couples will be better positioned to seek this aid. The many same-sex couples who cannot afford expensive tax advice will be left to answer these questions themselves - or, more likely, they may simply throw up their hands in frustration.

c. Traps for the unwary.-The IRS guidance also lays potentially dangerous traps for the unwary. For instance, the Supreme Court's same-sex marriage decision renewed attention on the plight of married same-sex couples who split up in states that refuse to let them divorce. ${ }^{65}$ These couples have learned the hard way that many states recognizing same-sex marriage impose strict residency requirements for divorce, leaving them no legal way out of their marriages. ${ }^{66}$ For married same-sex couples in this situation, the IRS guidance raises difficult (and, for some, nearly insuperable) hurdles to severing their marital relationships for federal tax purposes.

Under current tax law, the IRS cannot treat a couple as unmarried without state sanction. For filing purposes, a couple continues to be treated as married until a court issues a divorce or separation decree. ${ }^{67}$ Neither living apart nor signing a separation agreement will sever the marital relationship for this purpose. ${ }^{68}$ As a practical matter, this means that samesex couples who separate but cannot divorce must either file joint federal tax returns (and be on the hook for each other's tax bills) or file as married filing separately.

Married filing separately is not an attractive option, as evidenced by the very few taxpayers who choose this filing status. ${ }^{69}$ The married filing separately tax rates are higher than those for a joint return and, for some taxpayers, higher than those even for a single return. ${ }^{70}$ If one spouse filing separately itemizes deductions, then the other is denied the standard deduction. ${ }^{71}$ And married filing separately results in the reduction or complete denial of a variety of tax benefits, including the dependent care

65 E.g., Margaret Klaw, Gay Divorce, the Next Frontier, WASH. Post (July 5, 2013), http://articles.washingtonpost.com/2013-07-05/opinions/40390073_1_marriage-equality-marriagelicense-marriage-act.

66 E.g., MASS. ANN. LAWS ch. 208, §§ 4-5 (LexisNexis 2011).

67 See I.R.C. $\$ \$ 1,2,7703(\mathrm{a})(2)$.

68 Boris I. BITTKer \& LAWRENCE LOKKEN, FEDERAL TAXATION OF INCOME, ESTATES \& GIFTS II 111.3.6 (2013) ("Since a decree is required, separation agreements do not terminate the marriage for tax purposes ....”).

69 I.R.S. Pub. No. 1304, Individual Income Tax Returns 2010, at 39-40 tbl.1.2 (2012), available at http://www.irs.gov/pub/irs-soi/10inalcr.pdf (indicating that, for taxable year 2010, the number of married filing jointly returns was 53,526,090 while the number of married filing separately returns was 2,532,292).

70 See I.R.S., FORM 1040 INSTRUCTIONS 79-91 (2012).

71 I.R.C. $\S 63(\mathrm{c})(6)(\mathrm{A})$. 
assistance credit, adoption credit, earned income credit, and many tax benefits for education. ${ }^{72}$

There is, however, a temporary reprieve for married individuals who occupy, maintain, and furnish more than half the cost of a household that their dependent child uses as a principal place of abode for more than half the year. ${ }^{73}$ These individuals can qualify for head of household filing status, but will return to married filing separately once the last child leaves home. Naturally, this reprieve is unavailable to same-sex couples without children or to the noncustodial spouse in a same-sex couple that does have children. Unless one of the former spouses meets the residency requirements of a state that will divorce them, this disadvantageous tax status will follow them until they die.

d. Legal challenges.-The IRS guidance is likely to foster uncertainty by breeding litigation challenging its validity. Same-sex couples caught in the trap for the unwary described in the preceding section will have good reason to challenge the IRS guidance, as the alternative rule of determining marital status based on the couple's domicile would, in many cases, effectively end the marital relationship for federal tax purposes by denying it legal recognition. ${ }^{74}$ But even more likely to spawn litigation is the IRS's choice not to recognize civil unions and domestic partnerships that are the legal equivalent of marriage.

Just two years ago, the IRS indicated that it was open to recognizing different-sex couples' civil unions and domestic partnerships for federal tax purposes - so long as those relationships were the legal equivalent of marriage under state law. ${ }^{75}$ The letter conveying this position stated:

In general, the status of individuals of the opposite sex living in a relationship that the state would treat as husband and wife is, for Federal income tax purposes, that of husband and wife.... [T] he Illinois Religious Freedom Protection and Civil Union Act provides that "[A] party to a civil union is entitled to the same legal obligations, responsibilities, protections, and benefits as are afforded or recognizes [sic] by the law of Illinois to spouses ...." Accordingly, if Illinois treats the parties to an Illinois civil union who are of opposite sex as husband and wife, they are considered "husband and wife" for purposes of Section 6013 of the Internal Revenue Code, and are

${ }^{72} I d . \S \S 21(\mathrm{e})(2), 23(\mathrm{f})(1), 25 \mathrm{~A}(\mathrm{~g})(6), 32(\mathrm{~d}), 221(\mathrm{e})(2)$.

73 Id. $\$$ 7703(b).

74 Alternatively, if a couple is party to an evasive marriage and the IRS ultimately takes the position that its guidance is intended to cover evasive marriages, then the couple might ask a state court to declare their marriage invalid and avoid the need to divorce altogether. See supra Part II.B.2.a.

75 Amy S. Elliott, IRS Memo Indicates Civil Unions Are Marriages for Tax Purposes, 133 TAX NOTES 794, 794 (2011). 
not precluded from filing jointly, unless prohibited by other exceptions under the Code. ${ }^{76}$

Some commentators expressed surprise at this position, believing that the most important factor in determining whether a couple is married for federal tax purposes is whether their legal relationship carries the marriage label under state law. ${ }^{77}$ In its post-Windsor guidance, the IRS reversed course and embraced the commentators' view by exalting the importance of the marriage label and ignoring the legal equivalence of these relationships. With absolutely no analysis at all, the IRS concluded:

For Federal tax purposes, the terms "spouse," "husband and wife," "husband," and "wife" do not include individuals (whether of the opposite sex or the same sex) who have entered into a registered domestic partnership, civil union, or other similar formal relationship recognized under state law that is not denominated as a marriage under the laws of that state, and the term "marriage" does not include such formal relationships. ${ }^{78}$

It is this more recent position that is surprising, even a bit shocking. If any area of federal law were to recognize domestic partnerships and civil unions as marriages, one would expect it to be tax law because "[t]he principle of looking through form to substance... is the cornerstone of sound taxation." 79 Looking to substance rather than to form, domestic partnerships and civil unions that are marriages all but in name should be treated as marriages for federal tax purposes. What makes this position shocking is the comparative lack of analysis supporting it. The IRS's postWindsor guidance is quite detailed - much more than is typical of a revenue ruling - and actually contains pages of analysis justifying the IRS's decision to adopt a gender-neutral reading of the gendered terms husband and wife. The IRS went to great pains to explain why the labels husband and wife should not control the tax consequences of married same-sex couples but rather that it should be the equivalence of the legal relationships that controls. In contrast, the IRS's position on civil unions and domestic partnerships is not the subject of similarly lengthy legal analysis; in fact, the IRS provides no legal analysis to support its position at all.

Couples in civil unions and domestic partnerships are well-advised to contest the IRS's change in its position. There is no tax policy justification for affording radically different tax treatment to couples who are in legally similar relationships (with the exception of the label applied to those

${ }^{76}$ Letter from Pamela Wilson Fuller, Senior Technician Reviewer, I.R.S., to Robert Shair, Senior Tax Advisor, H\&R Block (Aug. 30, 2011) (alteration in original) (emphasis added) (citation omitted), available at http://www.proskauer.com/files/uploads/Documents/IRS-Letter-2011-on-Civil-Unions-inIllinois.pdf.

77 Elliott, supra note 75, at 794.

78 Rev. Rul. 2013-17, 2013-38 I.R.B. 201.

79 Estate of H.H. Weinert v. Comm'r, 294 F.2d 750, 755 (5th Cir. 1961). 
relationships). The fact that the IRS made no attempt whatsoever to justify this distinction in treatment - other than to point to the importance of labels that it had just pages earlier argued do not matter-will only make this guidance all the more vulnerable when subject to legal challenge.

By overriding the majority of states' marriage laws, the IRS guidance is plagued by the same federalism concerns that made Section 3 of DOMA vulnerable to constitutional challenge..$^{80}$ Although the states themselves may have trouble establishing standing to challenge the IRS guidance on federalism grounds, ${ }^{81}$ married same-sex couples caught in traps for the unwary and couples (same-sex or different-sex) in civil unions and domestic partnerships would have standing - and, more importantly, great incentive - to challenge the IRS's position. The inevitable litigation challenging the validity of the IRS's position will do nothing more than breed additional uncertainty regarding the tax treatment of same-sex couples post-Windsor.

e. Interaction with state tax law.-The IRS guidance will also impose significant administrative and tax-filing burdens on married samesex couples in states that do not recognize same-sex marriage, just as Section 3 of DOMA did to same-sex couples in states that legally recognized their relationships. Pre-Windsor, same-sex couples whose relationships were legally recognized by a state were normally required to file two federal income tax returns using single or head of household status. ${ }^{82}$ However, on their state income tax returns, these couples usually could not file using single or head of household status. ${ }^{83}$ Because state income tax laws often piggyback on the federal income tax, this created a nonconformity of filing status (e.g., single or head of household at the federal level and married filing jointly or married filing separately at the state level). This noncomformity led to added complexity — and often added compliance burdens - for same-sex couples ${ }^{84}$ For example, commentators predicted that "this nonconformity will produce higher tax preparation costs, higher state audit risks (when states are confused by differences on the state and federal returns), and more expense in dealing with state

\footnotetext{
${ }^{80}$ United States v. Windsor, 133 S. Ct. 2675, 2691-92 (2013); see supra notes 20 and 26, and accompanying text.

81 In contrast, Section 3 of DOMA clearly harmed states recognizing same-sex marriages, leading to a constitutional challenge by the Commonwealth of Massachusetts. Massachusetts v. U.S. Dep't of Health \& Human Servs., 698 F. Supp. 2d 234 (D. Mass. 2010), aff'd, 682 F.3d 1 (1st Cir. 2012).

82 Carlton Smith \& Edward Stein, Dealing with DOMA: Federal Non-Recognition Complicates State Income Taxation of Same-Sex Relationships, 24 COLUM. J. GENDER \& L. 29, 33 (2012).

${ }^{83}$ Id. at 49-50. Colorado's civil union regime is a notable exception to this general rule. CoLO. REV. STAT. § 14-15-117 (2013).

${ }^{84}$ Smith \& Stein, supra note 82 , at $49-81$.
} 
inquiries concerning conforming changes after federal audit changes have been made." $" 85$

Post-Windsor, the IRS's approach to recognizing same-sex marriage creates a mirror image of this problem. With valid same-sex marriages recognized regardless of the law of the couple's state of residence, same-sex couples living in states that do not recognize their marriages will be required to file as married filing jointly or married filing separately for federal purposes but will be prohibited from using those statuses when filing their state tax returns. This nonconformity will give rise to precisely the same complexity and administrative burden that existed pre-Windsor; it will just be a different group of same-sex couples that will be burdened (i.e., those who are already saddled with state nonrecognition of their relationships).

f. Entrenching the privileging of marriage.-The IRS guidance also further entrenches the privileged status of marriage in the federal tax laws instead of fostering the recognition of a more diverse array of human relationships for federal tax purposes. Far from being marriage- or relationship-neutral, the Internal Revenue Code has been characterized as "a scheme of taxation where considerations of marital status are pervasive." Pre-Windsor, the federal tax laws recognized only different-sex marriages and traditional family structures built around different-sex married couples. $^{87}$

As described above ${ }^{88}$ the IRS guidance takes a formalistic approach in determining which relationships merit recognition for federal tax purposes. According to the IRS, civil unions and domestic partnerships will not be recognized for federal tax purposes, even if they are the legal equivalent of a marriage. The IRS thus continues to confine the relationships that are recognized for tax purposes to marriage - and, now, only to marriage, without the possibility of recognizing any relationship that carries a different label.

The IRS guidance effectively crowds out all other relationships and permits marriage to occupy the field. In the short term, this creates a strong incentive for couples in states with only civil unions or domestic partnerships to travel to one of the states that will allow them to marry, so long as that marriage will be valid and recognized for federal tax purposes. In the long term, it creates a strong incentive for civil union and domestic partnership states to abandon those relationship recognition regimes in

\footnotetext{
85 Id. at 34.

${ }^{86}$ Nancy J. Knauer, Heteronormativity and Federal Tax Policy, 101 W. VA. L. REV. 129, 132 (1998).

87 Anthony C. Infanti, LGBT Families, Tax Nothings, J. GENDER RACE \& JUST. (forthcoming 2013), available at $\mathrm{http}: / /$ papers.ssrn.com/sol3/papers.cfm?abstract_id=2231511.

88 See supra Part II.B.2.d.
} 
favor of same-sex marriage. Moreover, any state that currently refuses to recognize same-sex relationships but later considers a change in its legal treatment of same-sex couples will choose to extend marriage to those couples rather than explore alternative options that might be afforded to all couples. For example, the District of Columbia currently provides couples the choice between registering as domestic partners with a more limited set of rights and obligations or to marry and have all of the rights and obligations of married spouses ${ }^{89}{ }^{8}$ In the future, states will be less likely to provide such different options for relationship recognition because the federal tax laws place a thumb firmly on the scales in favor of marriage.

Had the IRS chosen to recognize domestic partnerships and civil unions that are the legal equivalent of marriage, it would have taken a step in the direction of loosening the grip that marriage has had on the federal tax laws. By opening the door to alternatives to marriage, the IRS could have laid the groundwork for eventually extending recognition to other relationships that entail the same type of entanglement as marriage but come with a more limited set of rights and obligations. For example, the IRS might eventually have acknowledged that couples in reciprocal beneficiary or designated beneficiary relationships make the same type of commitment that led policymakers to rely upon marital status as a factor in determining tax consequences. Instead, the IRS has chosen to ignore the commitments made by some while honoring the commitments made by others. This could result in adverse tax consequences for some and tax benefits for others that are wholly unrelated to any tax policy justification and are driven only by the choice to privilege marriage - and only marriage-in the federal tax laws.

There is also reason to be concerned about the intersection of this privileging of marriage with class (as well as race and gender) - a problem highlighted at several points above.$^{90}$ Income inequality in the United States has been growing over the past several decades. Economists Anthony Atkinson, Thomas Piketty, and Emmanuel Saez have shown that the share of income going to the top $10 \%$ of the population in the United States has significantly spiked since the 1970s. ${ }^{91}$ Research in the area of income inequality has now begun to focus on how changes in family structure and

89 Prior to permitting same-sex couples to marry, the District of Columbia permitted them to enter into domestic partnerships that afforded more limited rights and obligations. E.g., D.C. CoDE $§ 32-701$ to -710 (LexisNexis 2001). Even after the extension of marriage to same-sex couples, couples still have the option of entering into a domestic partnership. Id. §§ 32-701, -702(d)(3), (i), (j).

90 See supra Part II.B.

91 See Anthony B. Atkinson et al., Top Incomes in the Long Run of History, 49 J. ECON. LiterATURE 3, 6 (2011). The share of total income going to the top $10 \%$ reached nearly $50 \%$ by 2007 , which is "the highest level on record." Id. Most of this change benefited the top 1\%, which saw its share of income increase "from 8.9 percent in 1976 to 23.5 percent in 2007." Id. The top $0.1 \%$ has done even better, with its share of income having "more than quadrupled from 2.6 percent to 12.3 percent over this period." Id. 
composition affect income inequality and also have negative impacts along lines of race and gender. ${ }^{92}$ Indeed, a review of this literature points to the division of marriage along class lines (with decreases in marriage concentrated at lower income levels) and concludes that "[t]here is strong support for the hypothesis that increases in single mother families and decreases in married couple families have increased income inequality." 93 Or, as the popular press has summed it up: "[S]triking changes in family structure have also broadened income gaps and posed new barriers to upward mobility.... [M] otherhood outside marriage now varies by class about as much as it does by race," and "marriage and its rewards [are] evermore confined to the fortunate classes." 94 To the extent that there is an association between marriage and growing income inequality, further entrenching the privileged status of marriage in the tax laws-which are often viewed as one of the primary tools for reducing income inequalitymay only exacerbate income inequality along lines of class, race, and gender.

In light of the numerous problems associated with the IRS's implementation of the Windsor decision, we should take this opportunity to pause and consider more fundamental reforms of the tax system-ones that might both better address these problems and improve the tax system for everyone. So long as the patchwork of legal recognition of same-sex relationships continues among the states, the IRS is going to find it impossible to come up with a workable and fair solution for addressing the tax treatment of same-sex couples. With this future in mind, it is worth recalling that commentators have for decades been leveling devastating critiques at the choice to adopt the married couple as a taxable unit. ${ }^{95}$ This literature suggests an easier and fairer approach than that adopted by the IRS - one that would address the plight of same-sex couples and improve the overall fairness of the federal tax system. Under this approach, we would eliminate the privileging of marriage in the federal tax laws by adopting the individual as the taxable unit. This approach avoids the need to determine when and how to take same-sex marriage into account for federal tax purposes. It also holds the promise of a relationship-neutral tax system that could recognize a wide array of human relationships. Indeed, I have elsewhere outlined a proposal for individual income tax filing that is designed to recognize all economically interdependent relationships for tax

\footnotetext{
92 See, e.g., Sarah McLanahan \& Christine Percheski, Family Structure and the Reproduction of Inequalities, 34 ANN. REV. Soc. 257, 269-71 (2008); Molly A. Martin, Family Structure and Income Inequality in Families with Children, 1976 to 2000, 43 DEMOGRAPHY 421, 436-39 (2006).

93 Leslie McCall \& Christine Percheski, Income Inequality: New Trends and Research Directions, 36 ANN. REV. Soc. 329, 335, 337 (2010).

94 Jason DeParle, Two Classes, Divided by “I Do," N.Y. TIMES (July 14, 2012), http://www.nytimes.com/2012/07/15/us/two-classes-in-america-divided-by-i-do.html.

95 Anthony C. Infanti, Decentralizing Family: An Inclusive Proposal for Individual Tax Filing in the United States, 2010 UTAH L. REV. 605, 614-18.
} 
purposes and not just those patterned after marriage or even those that are conjugal in nature. ${ }^{96}$ The time is ripe to revisit such proposals and to seriously consider their adoption.

\section{CONCLUSION}

Appearances can be deceiving. Just as the moon is not simply shiny and bright but also pocked with the evidence of prior violent impacts, the tax "equality" that same-sex couples have achieved with the invalidation of Section 3 of DOMA seems appealing but is actually a terrain fraught with the effects of prior discrimination and filled with new pitfalls for same-sex couples and adverse effects on others. In fact, it is only after having attained this "equal" status that the real work of achieving equal treatment for allwhether married or not-begins.

96 Id. at 638-63. 